\title{
Synthesis and Antimicrobial Activity of Some Novel N-Mannich Bases of Imidazole Phenylazetidin-2-one
}

\section{Esther Rani V ${ }^{1 *}$ and Kanderi Dileep Kumar ${ }^{2}$}

${ }^{1}$ Department of Chemistry, Sri Krishnadevaraya University, Anantapur, India

${ }^{2}$ Department of Microbiology, Sri Krishnadevaraya University, Anantapur, India

\begin{abstract}
The novel derivative of $\beta$-lactams of Imidazole phenylazetidin-2-ones $7(a-h)$ are an important class of heterocycles, having potential biological importance due to their unique features. The process of convert of imine (Schiffs base) to azetidine ( $\beta$-lactam) through an intermediate of monochloro acetyl chloride is important synthetic method for preparation of azetidine-2-ones.
\end{abstract}

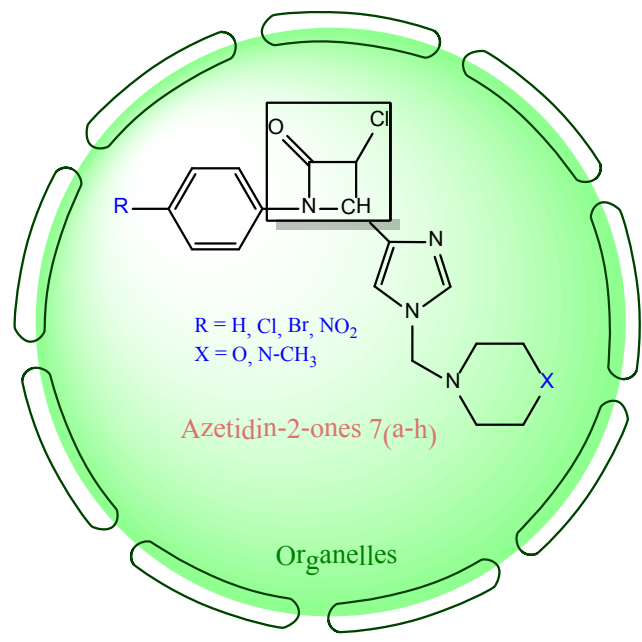

Keywords: Azetidin-2-one; Imidazole carboxaldehyde; Antimicrobial activity

\section{Introduction}

Azetidine-2-one ( $\beta$-lactam) chemistry is of great importance because of the use of $\beta$-lactam derivatives as antibacterial agents. Since the discovery that the structure of penicillin contains a $\beta$-lactam function, a vast amount of effort has been devoted to producing other $\beta$-lactam antibiotics with a wider spectrum of activity and a greater resistance to enzymic cleavage by $\beta$-lactamases. The synthesis of $\beta$-lactam antibiotics has occupied an important place in the field of medicinal and research pharmaceutical. The antibiotic activity of Azetidine-2-ones ( $\beta$-lactam) possessing antiviral, antifungal activities, antithrombotic and cholesterol inhibition [1-4].

The various synthetic approaches to obtain heterocyclic 2-azetidinones have been reported [5-14]. In the present paper, we describe the synthesis of heterocycles comprising Azetidin-2-one of $\mathrm{N}$-Mannich Bases of Imidazole phenylazetidin-2-ones which can be an attractive target to obtain a series of novel compounds with potentially wide range of biological activity such as cholesterol absorption inhibitors, enzyme inhibitors, anticancer, cytotoxic, antitubercular, antitumor and antimicrobial (Scheme 1).

\section{Experimental Section}

\section{Instrumentation and chemicals}

All the chemicals used in the present investigation were purchased from Sigma-Aldrich Chemicals company, Inc. USA. And used without further purification. Thin Layer Chromatography was performed on aluminium sheet of silica gel 60F254, E-Merk, Germany using iodine as visualizing agent. Melting points were determined in open capillary tubes on Mel-Temp apparatus and are uncorrected. Column chromatography was performed on silica gel with different solvent systems as eluents to afford the pure compound. The IR Spectra were recorded as $\mathrm{KBr}$ pellets on Perkin-Elmer 1000 units, instruments. All ${ }^{1} \mathrm{H}$ and ${ }^{13} \mathrm{C}-\mathrm{NMR}$ spectra were recorded on a Varian $\mathrm{XL}-300$ spectrometer operating at $400 \mathrm{MHz}$ for ${ }^{1} \mathrm{H}-\mathrm{NMR}$ and $75 \mathrm{MHz}$ for ${ }^{13} \mathrm{C}$-NMR. The compounds were dissolved in DMSO- $\mathrm{d}_{6}$ and Chemical shifts were referenced to TMS $\left({ }^{1} \mathrm{H}\right.$ and $\left.{ }^{13} \mathrm{C}-\mathrm{NMR}\right)$. Mass spectral data was recorded on FAB-MS instrument at $70 \mathrm{ev}$ with direct inlet system. Elemental analysis was recorded on a Carlo Erba 1108 elemental Analyzer, Central Drug Research Institute, Lucknow, India.

\section{Microbial assay (Agar well diffusion method)}

Nutrient agar (Bacto-beef extract $3 \mathrm{~g}$; peptone $5 \mathrm{~g}$; $\mathrm{NaCl} 5 \mathrm{~g}$; and distilled water $1000 \mathrm{~mL}$ ) was used for bacteria growth and Asthana and

*Corresponding author: Esther Rani V, Department of Chemistry, Sri
Krishnadevaraya University, Anantapur, India, E-mail: vesther9@gmail.com Received March 12, 2015; Accepted April 03, 2015; Published April 05, 2015

Citation: Rani VE, Kumar KD (2015) Synthesis and Antimicrobial Activity of Some Novel N-Mannich Bases of Imidazole Phenylazetidin-2-one. Med chem 5: 154-159. doi:10.4172/2161-0444.1000258

Copyright: ( 2015 Rani VE, et al. This is an open-access article distributed under the terms of the Creative Commons Attribution License, which permits unrestricted use, distribution, and reproduction in any medium, provided the original author and source are credited. 


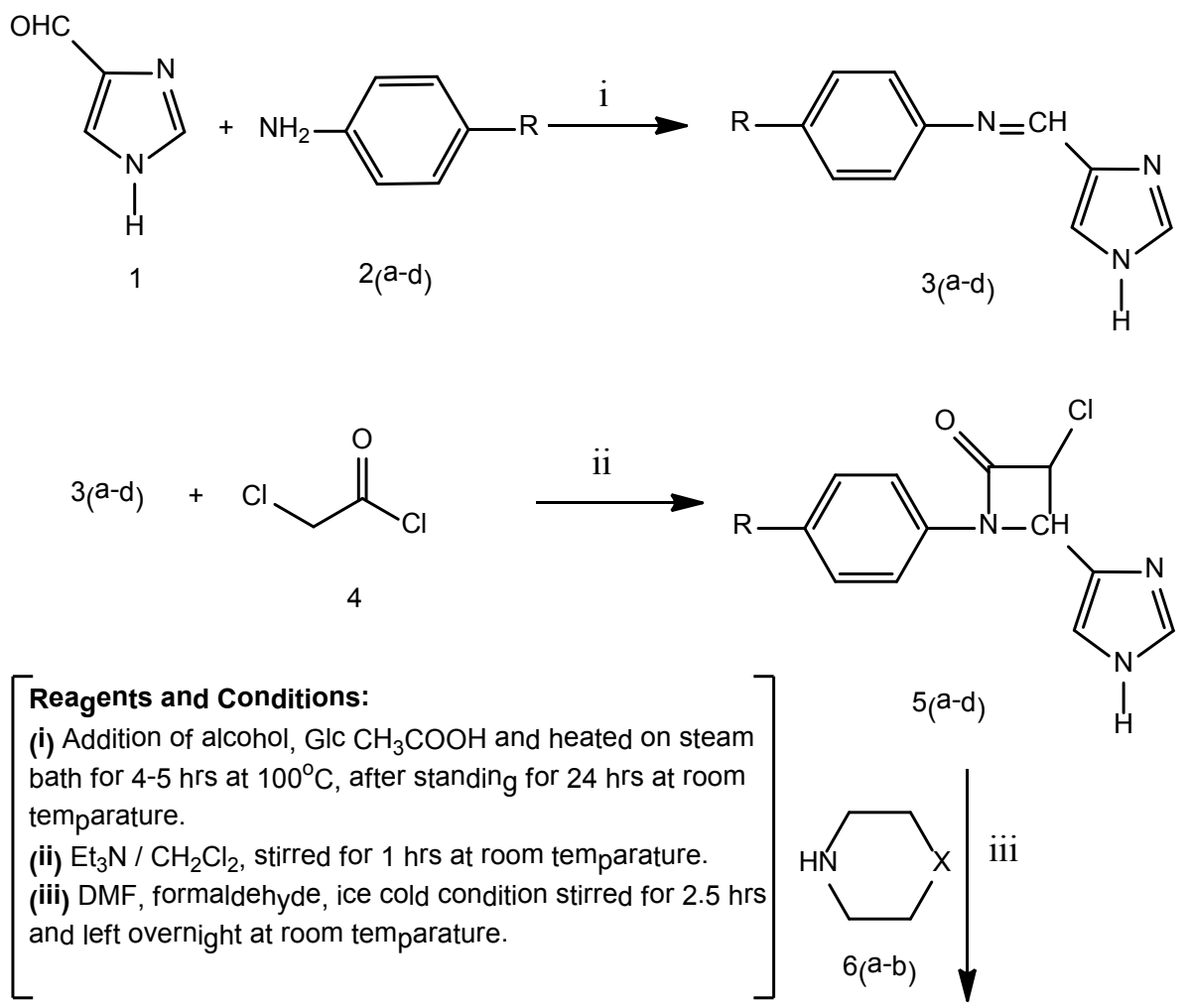

$\begin{array}{llllll}\text { Comp } & \mathbf{R} & \mathbf{X} & \text { Comp } & \mathbf{R} & \mathbf{X} \\ 7 \mathrm{a} & \mathrm{H} & \mathrm{O} & 7 \mathrm{e} & \mathrm{H} & \mathrm{N}-\mathrm{CH}_{3} \\ 7 \mathrm{~b} & \mathrm{Cl} & \mathrm{O} & 7 \mathrm{f} & \mathrm{Cl} & \mathrm{N}-\mathrm{CH}_{3} \\ 7 \mathrm{c} & \mathrm{Br} & \mathrm{O} & 7 \mathrm{~g} & \mathrm{Br} & \mathrm{N}-\mathrm{CH}_{3} \\ 7 \mathrm{~d} & \mathrm{NO}_{2} & \mathrm{O} & 7 \mathrm{~h} & \mathrm{NO} & \mathrm{N}-\mathrm{CH}_{3}\end{array}$

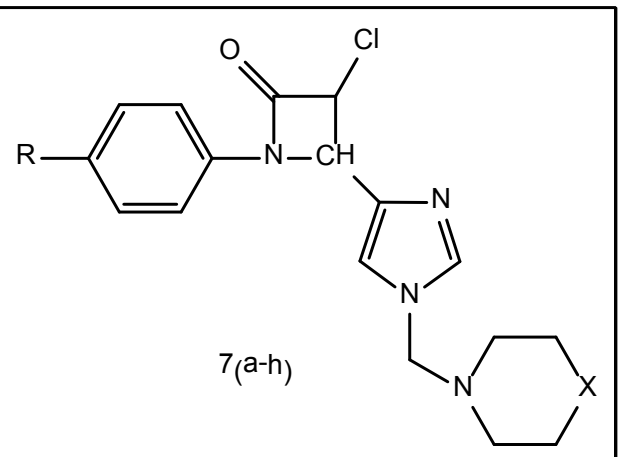

Scheme 1: Synthesis of 3-chloro-4-(1-(morpholinomethyl) / ((4-methylpiperazin-1-yl) methyl)-1H-imidazol-4-yl)-1-(4-substituted phenyl) azetidin-2-one 7(a-h).

Hawker's (Glucose 5 gr; $\mathrm{KNO}_{3} 3.5 \mathrm{~g} ; \mathrm{KH}_{2} \mathrm{PO}_{4} 1.75 \mathrm{~g} ; \mathrm{MgSO}_{4} .7 \mathrm{H}_{2} \mathrm{O} 0.75$ $\mathrm{g}$ and distilled water $1000 \mathrm{~mL}$ ) media used for fungi growth. The media chemicals present study purchased from Merck. The standard bacterial and fungal strains were procured from the Microbial Type Culture Collection (MTCC), Institute of Microbial Technology (IMTECH), and Chandigarh, India. The pure bacterial cultures were maintained on Nutrient Agar Media (NAM) for bacterial and fungal culture on potato dextrose agar (PDA).

The antimicrobial activity of these newly synthesized 3-chloro4-(1-(morpholinomethyl) / ((4-methylpiperazin-1-yl) methyl)1H-imidazol-4-yl)-1-(4-substituted phenyl) azetidin-2-one 7(a-h) performed according to Agar well diffusion method is preferred to be used in this study since it was found to be better than the disc diffusion method suggested by Parekh et al. [15] and also recommended by the National Committee for Clinical Laboratory. The synthesized compounds were used at the concentration of $2 \mathrm{mg} / \mathrm{mL}$ DMSO as a solvent [16]. A standardized 1 to $2 \times 10^{7} \mathrm{cfu} / \mathrm{mL} 0.5 \mathrm{MC}$ Farland standard was introduced onto the surface of a sterile agar plate and evenly distributed inoculums by using a sterile glass spreader. Simultaneously, $6 \mathrm{~mm}$ wells were cut from the plate using a sterile cork borer. $50 \mu \mathrm{l}$ solution at a concentration of $2 \mathrm{mg} / \mathrm{mL}$ of the compounds was introduced into well and incubated at $37^{\circ} \mathrm{C}$ for $24 \mathrm{hrs}$, the inhibition zones were measured with a ruler and compared with the control well containing only $1 \mathrm{mg} / \mathrm{mL}$ in DMSO of streptomycin as the standard. The antifungal assay of the compounds was carried out by agar well diffusion method as described by Magaldi et al. [17] $6 \mathrm{~mm}$ diameter open wells punched with a sterile cork borer on cultured plates with test organisms before incubated. The wells were filled with $50 \mu$ solution at a concentration of $2 \mathrm{mg} / \mathrm{mL}$ of the compounds at $30^{\circ} \mathrm{C}$. After 72 hours, the zones of inhibition were measured and compared with those of the control DMSO and the standard Fluconazole at a concentration of $1 \mathrm{mg} / \mathrm{mL}$.

\section{Antibacterial assay}

The antibacterial activity of 3-chloro-4-(1-(morpholinomethyl) ((4-methylpiperazin-1-yl) methyl)-1H-imidazol-4-yl)-1-(4-substituted phenyl) azetidin-2-one 7(a-h) were screened against the Staphylococcus 
aureus (MTCC-3160) and Bacillus subtilis (MTCC-441) (gram +ve) and Escherichia coli (MTCC-1652) and Pseudomonas aeruginosa (MTCC-467) (gram -ve) organisms. Here Streptomycin is tested as reference compound to compare the activity.

\section{Antifungal assay}

Antifungal activity of 3-chloro-4-(1-(morpholinomethyl) / ((4-methylpiperazin-1-yl) methyl)-1H-imidazol-4-yl)-1-(4-substituted phenyl) azetidin-2-one 7(a-h) were screened against Aspergillus niger (MTCC-282) and Penicillium rubrum, our isolate. Here Fluconazole is tested as reference compound to compare the activity. The anti-bcterial and anti-fungal activity of $7(\mathrm{a}-\mathrm{h})$ were shown in the Table 1.

Synthesis of $\mathrm{N}-((1 \mathrm{H}$-imidazol-4-yl) methylene) 4-substituted aniline 3(a-d): The aniline $(0.93 \mathrm{~g}, 0.01 \mathrm{~mol})$ (2a) and 4 -imidazole carboxaldehyde $(0.67 \mathrm{~g}, 0.007 \mathrm{~mol}$ ) (1) were dissolved in absolute alcohol, to this three drops of glacial acetic acid is added then heated on a steam bath for $4-5$ hours at $100^{\circ} \mathrm{C}$. After standing for 24 hours at room temperature. The organic layer the solution was dried over anhydrous sodium sulfate. After the evaporation of the solvent, the residue was purified by column chromatography (60-120 mesh silica gel, eluent: $10 \%$ EtoAc pet ether $)$. Finally, the product compound $\mathrm{N}-((1 \mathrm{H}-$ imidazol-4-yl) methylene) aniline (3a) which was recrystallized from warm absolute alcohol. Yield $72 \%$ with $0.85 \mathrm{~g}, \mathrm{~m} \mathrm{p} 154-156^{\circ} \mathrm{C}$.

The similar procedure was adopted to synthesize $3(\mathrm{~b}-\mathrm{d})(3 \mathrm{~b}-1.02 \mathrm{~g}$ with $72 \%, 3 \mathrm{c}-1.25 \mathrm{~g}$ with $68 \%$ and $3 \mathrm{~d}-1.08 \mathrm{~g}$ with $66 \%$ ) by condensing 2-imidazole carboxaldehyde $(0.67 \mathrm{~g}, 0.007 \mathrm{~mol})$ (1) with 4-chloro aniline $(2 \mathrm{~b}-0.93 \mathrm{~g}, 0.01 \mathrm{~mol})$, 4-bromo aniline $(2 \mathrm{c}-1.27 \mathrm{~g}, 0.01 \mathrm{~mol})$ and 4-nitro aniline (2d-1.38g, $0.01 \mathrm{~mol})$ respectively.

Synthesis of 3-chloro-4-(1H-imidazol-4-yl)-1-(4-substituted phenyl) azetidin-2-one 5(a-d): The imine (Schiff's base) (0.51g, 0.003 mol) (3a) was placed in $50 \mathrm{~mL}$ round bottom flask equipped with a magnetic pallet at nitrogen atmosphere, followed by addition of monochloro acetyl chloride $(0.67 \mathrm{~g}, 0.006 \mathrm{~mol})$ (4) and triethyl amine (5droups, $0.2 \mathrm{~mL}$ ) in $\mathrm{CH}_{2} \mathrm{Cl}_{2}(25 \mathrm{~mL})$ at room temperature. The mixture was stirred for 1 hours and left at room temperature for 72 hours. The progress of reaction was monitored by Thin Layer Chromatography using cyclohexane and ethyl acetate (7:3) solvent mixture as a mobile phase. The mixture was poured on crushed ice. The product 3-chloro4-(1H-imidazol-4-yl)-1-phenylazetidin-2-one (5a) thus formed was filtered and washed with sodiumbicarbonate solution. The solution was dried over anhydrous sodium sulfate. After the evaporation of the solvent, the residue was purified by column chromatography (60120 mesh silica gel,eluent: $10 \%$ EtoAc pet ether). The dried product recrystallised with absolute alcohol, $\mathrm{mp} 148-150^{\circ} \mathrm{C}$ and yield $(0.52 \mathrm{~g})$ $70 \%$.

The similar procedure was adopted to synthesize $5(\mathrm{~b}-\mathrm{d})$ (5b$0.57 \mathrm{~g}$ with $68 \%, 5 \mathrm{c}-0.60 \mathrm{~g}$ with $65 \%$ and $5 \mathrm{~d}-0.59 \mathrm{~g}$ with $68 \%$ ) by condensing Schiffs bases 3(b-d) (3b-0.61 g, 3c-0.70 g and 3d-0.60 g) with monochloro acetyl chloride $(0.67 \mathrm{~g}, 0.006 \mathrm{~mol})$ (4) respectively.

Synthesis of 3-chloro-4-(1-(morpholinomethyl) methyl)-1Himidazol-4-yl)-1-(4-substituted phenyl) azetidin-2-one $7(\mathrm{a}-\mathrm{h})$ : A mixture of $(0.49 \mathrm{~g}, 0.002 \mathrm{~mol}) 3$-chloro - 4 - (1H - imidazol - 4 - yl) - 1 -phenylazetidin - 2 - one (5a), morpholine (6a) (0.5 g, 0.006 mol) and water $20 \mathrm{~mL}$ was stirred to obtained a clear solution. To this solution, Farmaldehide $(0.05 \mathrm{~mol}, 15 \mathrm{~mL})$ and DMF $(10 \mathrm{ml})$ were added in ice cold condition and stirred for 2 hours in an ice bath and left over night at room temperature. The progress of the reaction was monitored by Thin Layer Chromatography using cyclohexane and ethylacetate (7:3) solvent mixture as a mobile phase. At the end of the reaction dichloromethane $(30 \mathrm{ml})$ was added to the mixture followed by neutralization with $50 \mathrm{ml}$ of $1 \mathrm{~N} \mathrm{NaOH}$ solution, after neutralization the mixture was extracted with $\mathrm{CH}_{2} \mathrm{Cl}_{2}(3 \times 25 \mathrm{~mL})$. The combined extract was dried on anhydrous $\mathrm{Na}_{2} \mathrm{SO}_{4}$. After filtration, the solvent was removed with rota evaporator. The residue was purified by column chromatography, using 60-120 mesh silica and $\mathrm{CHCl}_{3}$ solvent was used as an elutent. Finally the product 3-chloro-4-(1-(morpholinomethyl)1H-imidazol-4-yl)-1-phenylazetidin-2-one (7a) was purified from aqueous dimethyl formamide. Yield $70 \%$ with $0.47 \mathrm{~g}, \mathrm{~m} \mathrm{p} 162-164^{\circ} \mathrm{C}$.

The similar procedure was adopted to synthesize $7(\mathrm{~b}-\mathrm{d})$ by condensing 5 (b-d) (5b-0.56 g, 5c-0.65 g and $5 \mathrm{~d}-0.58 \mathrm{~g}$ ) with morpholine $(0.5 \mathrm{~g}, 0.006 \mathrm{~mol})(6 \mathrm{a})$ respectively.

The structure of these newly synthesized compounds of $7(\mathrm{a}-\mathrm{d})$ were established by IR, ${ }^{1} \mathrm{H}-\mathrm{NMR},{ }^{13} \mathrm{C}-\mathrm{NMR}$, mass data and elemental analysis.

3-chloro-4-(1-(morpholinomethyl)-1H-imidazol-4-yl)-1phenylazetidin-2-one (7a) The product was synthesized according to general procedure $\mathbf{5 . 3}$ to afford the target compound as a white solid with $0.47 \mathrm{~g}(68 \%)$ and $\mathrm{m} \mathrm{p} 162-164^{\circ} \mathrm{C}$.

IR (KBr 4000-400 cm$\left.^{-1}\right)$ : 3062 (stretching of Ar-H), 2940 and 2895 $\left(\mathrm{CH}_{2}\right.$ of aliphatic- $\left.\mathrm{CH}\right), 1690(\mathrm{C}=\mathrm{O}$ of azetidinone $), 1560(\mathrm{C}-\mathrm{N}), 1478$ -

\begin{tabular}{|c|c|c|c|c|c|c|c|c|c|}
\hline \multirow{3}{*}{ Entry } & \multirow{3}{*}{ COMP } & \multirow{3}{*}{$\mathrm{R}$} & \multirow{3}{*}{$\mathrm{x}$} & \multicolumn{6}{|c|}{$\begin{array}{l}\text { Zone of inhibition (mm) } \\
\qquad 50 \mu \mathrm{L} \text { for well }\end{array}$} \\
\hline & & & & \multicolumn{4}{|c|}{${ }^{1}$ Anti-bacterial activity } & \multicolumn{2}{|c|}{${ }^{2}$ Anti-fungal activity } \\
\hline & & & & S.a & B.s & E.c & P.a & A.n & P.r \\
\hline 1 & $7 a$ & $\mathrm{H}$ & $\mathrm{O}$ & 12 & 14 & 10 & 09 & 07 & 05 \\
\hline 2 & $7 \mathrm{~b}$ & ${ }^{*} \mathrm{Cl}$ & $\mathrm{O}$ & 16 & 18 & 13 & 12 & 09 & 12 \\
\hline 3 & $7 \mathrm{c}$ & ${ }^{*} \mathrm{Br}$ & $\mathrm{O}$ & 18 & 16 & 15 & 11 & 14 & 10 \\
\hline 4 & $7 d$ & ${ }^{*} \mathrm{NO}_{2}$ & $\mathrm{O}$ & 15 & 13 & 10 & 16 & 13 & 12 \\
\hline 5 & $7 e$ & $\mathrm{H}$ & $\mathrm{NCH}_{3}$ & 11 & 07 & 09 & 10 & 04 & 06 \\
\hline 6 & $7 f$ & ${ }^{*} \mathrm{Cl}$ & $\mathrm{NCH}_{3}$ & 17 & 12 & 15 & 18 & 11 & 13 \\
\hline 7 & $7 g$ & ${ }^{*} \mathrm{Br}$ & $\mathrm{NCH}_{3}$ & 19 & 16 & 12 & 14 & 09 & 08 \\
\hline 8 & $7 \mathrm{~h}$ & ${ }^{*} \mathrm{NO}_{2}$ & $\mathrm{NCH}_{3}$ & 17 & 13 & 11 & 14 & 12 & 14 \\
\hline \multicolumn{2}{|c|}{ Std } & \multicolumn{2}{|c|}{ Streptomycin } & 25 & 20 & 20 & 23 & - & - \\
\hline \multicolumn{2}{|c|}{ Std } & \multicolumn{2}{|c|}{ Fluconazole } & - & - & - & - & 18 & 15 \\
\hline
\end{tabular}

1S.a - Staphylococcus aureus, B.s - Bacillus subtilis, E.c - Escherichia coli,

P.a - Pseudomonas aeruginosa

${ }^{2}$ A.n - Aspergillus niger P.r - Penicillium rubrum

*Indicates more activity

Table 1: Anti-bcterial and anti-fungal activity of 3-chloro-4-(1-(morpholinomethyl) / ((4- methylpiperazin-1-yl) methyl)-1H-imidazol-4-yl)-1-(4-substituted phenyl) azetidin2-one $7(\mathrm{a}-\mathrm{h})$. 
1366 (bending vibrations of imidazole ring), $1140(\mathrm{C}-\mathrm{O})$ and $725 \mathrm{~cm}^{-1}$ (C-Cl).

${ }^{1} \mathrm{H}-\mathrm{NMR}\left(400 \mathrm{MHz}, \mathrm{DMSO}-\mathrm{d}_{6}\right): \delta_{\mathrm{PPM}} 2.50\left(\mathrm{t}, 4 \mathrm{H},\left(\mathrm{CH}_{2}\right)_{2}\right.$ of morpholine ring $\mathrm{J}=7.1 \mathrm{~Hz}), 3.65\left(\mathrm{t}, 4 \mathrm{H},\left(\mathrm{CH}_{2}\right)_{2}\right.$ of morpholine ring $\mathrm{J}=$ $7.1 \mathrm{~Hz}), 3.93(\mathrm{~m}, 1 \mathrm{H}, \mathrm{CH}$ of azetidine ring $), 4.69(\mathrm{~d}, 1 \mathrm{H}, \mathrm{CH}$ of azetidine ring $\mathrm{J}=7.1 \mathrm{~Hz}), 4.80\left(\mathrm{~s}, 2 \mathrm{H}\right.$ of $\left.\mathrm{CH}_{2}\right), 5.38(\mathrm{~d}, 1 \mathrm{H}, \mathrm{CH}$ of azetidine ring $\mathrm{J}=7.1 \mathrm{~Hz}), 6.88(\mathrm{~s}, 1 \mathrm{H}, \mathrm{CH}$ of imidazole ring), 7.27-7.40 (m, $5 \mathrm{H}$ of phenyl ring) and 7.83 (s, $1 \mathrm{H}$ of imidazole ring).

${ }^{13}$ C-NMR (75 MHz, DMSO-d $)$ : $\delta_{\mathrm{PPM}} \cdot 137.2,118.8,137.8,40.9$, $68.5,199.4,54.3,139.2,128.1,128.8,126.0,128.8,128.1,76.1,53.6,66.4$, 53.6 and 66.4 corresponding to $\mathrm{C}_{1}$ to $\mathrm{C}_{18}$ respectively. MS 345.12 for $\mathrm{C}_{18} \mathrm{H}_{20} \mathrm{ClN}_{3} \mathrm{O}_{2}$. Anal. Found (Calcd) C, 62.52 (61.72); H, $5.83(5.53) ; \mathrm{N}$, $12.15(11.55)$.

3-chloro-1-(4-chlorophenyl)-4-(1-(morpholinomethyl)-1Himidazol-4-yl) azetidin-2-one (7b) The product was synthesized according to general procedure $\mathbf{5 . 3}$ to afford the target compound as a yellow solid with $0.51 \mathrm{~g}(68 \%)$ and $\mathrm{m} p 154-156^{\circ} \mathrm{C}$.

IR (KBr 4000-400 cm$\left.~^{-1}\right)$ : 3052 (stretching of Ar-H), 2940 and 2895 $\left(\mathrm{CH}_{2}\right.$ of aliphatic- $\left.\mathrm{CH}\right), 1690$ (C=O of azetidinone), $1556(\mathrm{C}-\mathrm{N}), 1475-$ 1360 (bending vibrations of imidazole ring), $1100(\mathrm{C}-\mathrm{O})$ and $720 \mathrm{~cm}^{-1}$ (C-Cl).

${ }^{1} \mathrm{H}-\mathrm{NMR}(400 \mathrm{MHz}$, DMSO-d $): \delta_{\mathrm{PPM}} 2.50\left(\mathrm{t}, 4 \mathrm{H},\left(\mathrm{CH}_{2}\right)_{2}\right.$ of morpholine ring $\mathrm{J}=7.1 \mathrm{~Hz}), 3.65\left(\mathrm{t}, 4 \mathrm{H},\left(\mathrm{CH}_{2}\right)_{2}\right.$ of morpholine ring $\mathrm{J}=$ $7.1 \mathrm{~Hz}), 3.93(\mathrm{~m}, 1 \mathrm{H}, \mathrm{CH}$ of azetidine ring $), 4.69(\mathrm{~d}, 1 \mathrm{H}, \mathrm{CH}$ of azetidine $\operatorname{ring} \mathrm{J}=7.1 \mathrm{~Hz}), 4.80\left(\mathrm{~s}, 2 \mathrm{H}\right.$ of $\left.\mathrm{CH}_{2}\right), 5.38(\mathrm{~d}, 1 \mathrm{H}, \mathrm{CH}$ of azetidine ring $\mathrm{J}$ $=7.1 \mathrm{~Hz}), 6.88(\mathrm{~s}, 1 \mathrm{H}, \mathrm{CH}$ of imidazole ring), $7.42-7.45(\mathrm{~m}, 4 \mathrm{H}$ of chloro phenyl ring) and 7.83 (s, $1 \mathrm{H}$ of imidazole ring).

${ }^{13}$ C-NMR (75 MHz, DMSO-d $): \delta_{\mathrm{PPM}} \cdot 137.2,118.8,137.8,40.9$, $68.5,199.4,54.3,137.3,129.5,128.9,131.6,128.9,129.5,76.1,53.6,66.4$, 53.6 and 66.4 corresponding to $\mathrm{C}_{1}$ to $\mathrm{C}_{18}$ respectively.MS 379.09 for $\mathrm{C}_{18} \mathrm{H}_{19} \mathrm{Cl}_{2} \mathrm{~N}_{3} \mathrm{O}_{2}$. Anal. Found (Calcd) C, 56.85 (56.05); H, 5.04 (4.54); $\mathrm{N}, 11.05(10.45)$.

1-(4-bromophenyl)-3-chloro-4-(1-(morpholinomethyl)-1Himidazol-4-yl) azetidin-2-one (7c) The product was synthesized according to general procedure $\mathbf{5 . 3}$ to afford the target compound as a yellow solid with $0.55 \mathrm{~g}(65 \%)$ and $\mathrm{m}$ p $142-144^{\circ} \mathrm{C}$.

IR (KBr 4000-400 cm-1): 3055 (stretching of Ar-H), 2940 and 2895 $\left(\mathrm{CH}_{2}\right.$ of aliphatic- $\left.\mathrm{CH}\right), 1685$ (C=O of azetidinone), $1550(\mathrm{C}-\mathrm{N}), 1478$ 1371 (bending vibrations of imidazole ring), $1112(\mathrm{C}-\mathrm{O})$ and $718 \mathrm{~cm}^{-1}$ (C-Cl).

${ }^{1} \mathrm{H}-\mathrm{NMR}\left(400 \mathrm{MHz}, \mathrm{DMSO}-\mathrm{d}_{6}\right): \delta_{\mathrm{PPM}} 2.50\left(\mathrm{t}, 4 \mathrm{H},\left(\mathrm{CH}_{2}\right)_{2}\right.$ of morpholine ring $\mathrm{J}=7.1 \mathrm{~Hz}), 3.65\left(\mathrm{t}, 4 \mathrm{H},\left(\mathrm{CH}_{2}\right)_{2}\right.$ of morpholine ring $\mathrm{J}=$ $7.1 \mathrm{~Hz}), 3.93(\mathrm{~m}, 1 \mathrm{H}, \mathrm{CH}$ of azetidine ring $), 4.69(\mathrm{~d}, 1 \mathrm{H}, \mathrm{CH}$ of azetidine ring $\mathrm{J}=7.1 \mathrm{~Hz}), 4.80\left(\mathrm{~s}, 2 \mathrm{H}\right.$ of $\left.\mathrm{CH}_{2}\right), 5.38(\mathrm{~d}, 1 \mathrm{H}, \mathrm{CH}$ of azetidine ring $\mathrm{J}=7.1 \mathrm{~Hz}), 6.88(\mathrm{~s}, 1 \mathrm{H}, \mathrm{CH}$ of imidazole ring), 7.18-7.82 (m, $4 \mathrm{H}$ of bromo phenyl ring) and 7.83 (s, $1 \mathrm{H}$ of imidazole ring).

${ }^{13}$ C-NMR (75 MHz, DMSO-d $)$ ): $\delta_{\mathrm{PPM}} \cdot 137.2,118.8,137.8,40.9$, $68.5,199.4,54.3,138.2,130.3,131.7,120.4,131.7,130.3,76.1,53.6$, 66.4, 53.6 and 66.4 corresponding to $\mathrm{C}_{1}$ to $\mathrm{C}_{18}$ respectively.MS 423.03 for $\mathrm{C}_{18} \mathrm{H}_{19} \mathrm{BrClN}_{3} \mathrm{O}_{2}$. Anal. Found (Calcd) C, 50.90 (50.50); H, 4.51 (4.01); N, 9.89 (9.39)

3 - chloro - 4 - (1 -(morpholinomethyl) -1H- imidazol - 4 - yl) -1(4 - nitrophenyl) azetidin - 2 - one (7d) The product was synthesized according to general procedure $\mathbf{5 . 3}$ to afford the target compound as a yellow solid with $0.54 \mathrm{~g}(70 \%)$ and $\mathrm{m} \mathrm{p} 154-156^{\circ} \mathrm{C}$.

IR (KBr 4000-400 cm cm $\left.^{-1}\right): 3068$ (stretching of Ar-H), 2940 and 2895
( $\mathrm{CH}_{2}$ of aliphatic- $\left.\mathrm{CH}\right), 1675$ (C=O of azetidinone), $1560(\mathrm{C}-\mathrm{N}), 1550$ $1330\left(\mathrm{C}-\mathrm{NO}_{2}\right), 1476-1365$ (bending vibrations of imidazole ring), 1116 (C-O) and $715 \mathrm{~cm}^{-1}(\mathrm{C}-\mathrm{Cl})$.

${ }^{1} \mathrm{H}-\mathrm{NMR}$ (400 MHz, DMSO-d $): \delta_{\mathrm{PPM}} 2.50\left(\mathrm{t}, 4 \mathrm{H},\left(\mathrm{CH}_{2}\right)_{2}\right.$ of morpholine ring $\mathrm{J}=7.1 \mathrm{~Hz}), 3.65\left(\mathrm{t}, 4 \mathrm{H},\left(\mathrm{CH}_{2}\right)_{2}\right.$ of morpholine ring $\mathrm{J}=$ $7.1 \mathrm{~Hz}), 3.93(\mathrm{~m}, 1 \mathrm{H}, \mathrm{CH}$ of azetidine ring $), 4.69(\mathrm{~d}, 1 \mathrm{H}, \mathrm{CH}$ of azetidine ring $\mathrm{J}=7.1 \mathrm{~Hz}), 4.80\left(\mathrm{~s}, 2 \mathrm{H}\right.$ of $\left.\mathrm{CH}_{2}\right), 5.39(\mathrm{~d}, 1 \mathrm{H}, \mathrm{CH}$ of azetidine ring $\mathrm{J}=7.1 \mathrm{~Hz}$ ), $6.88(\mathrm{~s}, 1 \mathrm{H}, \mathrm{CH}$ of imidazole ring), 7.83 (s, $1 \mathrm{H}$ of imidazole ring) and 7.55-8.21 ( $\mathrm{m}, 4 \mathrm{H}$ of chloro phenyl ring).

${ }^{13}$ C-NMR (75 MHz, DMSO-d $): \delta_{\mathrm{PpM}} \cdot 137.2,118.8,137.8,40.9$, $68.5,199.4,54.3,145.3,129.0,124.0,145.2,124.0,129.0,76.1,53.6,66.4$ 53.6 and 66.4 corresponding to $\mathrm{C}_{1}$ to $\mathrm{C}_{18}$ respectively. MS 390.11 for $\mathrm{C}_{18} \mathrm{H}_{19} \mathrm{ClN}_{4} \mathrm{O}_{4}$. Anal. Found (Calcd) C, 55.32 (54.82); H, 4.90 (4.50); N, 14.34 (13.74).

2.4. Synthesis of 3 - chloro - 4-(1-((4-methylpiperazin-1-yl) methyl) -1H- imidazol-4-yl) - 1 - (4-substituted phenyl) azetidin-2 one $7(\mathrm{e}-\mathrm{h})$ :

A mixture of $(0.49 \mathrm{~g}, 0.002 \mathrm{~mol}) 3$ - chloro - 4 - (1H - imidazol 4 - yl) - 1 -phenylazetidin - 2 - one (5a), N-methylpiperazine ( $0.6 \mathrm{~g}$, $0.006 \mathrm{~mol})(\mathbf{6 b})$ and water $20 \mathrm{~mL}$ was stirred to obtain a clear solution. To this solution, Farmaldehide $(0.05 \mathrm{~mol}, 15 \mathrm{~mL})$ and DMF $(10 \mathrm{ml})$ were added in ice cold condition and stirred for 2 hours in an ice bath and left over night at room temperature. The progress of the reaction was monitored by Thin Layer Chromatography using cyclohexane and ethylacetate (7:3) solvent mixture as a mobile phase. At the end of the reaction dichloromethane $(30 \mathrm{ml})$ was added to the mixture followed by neutralization with $50 \mathrm{ml}$ of $1 \mathrm{~N} \mathrm{NaOH}$ solution, after neutralization the mixture was extracted with $\mathrm{CH}_{2} \mathrm{Cl}_{2}(3 \times 25 \mathrm{~mL})$. The combined extract was dried on anhydrous $\mathrm{Na}_{2} \mathrm{SO}_{4}$. After filtration, the solvent was removed with rota evaporator. The residue was purified by column chromatography, using 60-120 mesh silica and $\mathrm{CHCl}_{3}$ solvent was used as an elutent. Finally the product 3-chloro-4-(1-((4-methylpiperazin1-yl) methyl) - 1H - imidazol - 4 - yl) - 1 -phenylazetidin-2-one (7e) was purified from aqueous dimethyl formamide. Yield $68 \%$ with $0.48 \mathrm{~g}$, $\mathrm{m} \mathrm{p} 142-144^{\circ} \mathrm{C}$.

The similar procedure was adopted to synthesize $7(\mathbf{f}-\mathbf{h})$ by condensing $\mathbf{5}(\mathbf{b}-\mathbf{d}) \quad(\mathbf{5 b}-0.56 \mathrm{~g}, \mathbf{5 c}-0.65 \mathrm{~g}$ and $\mathbf{5 d}-0.58 \mathrm{~g})$ with $\mathrm{N}$-methylpiperazine $(0.6 \mathrm{~g}, 0.006 \mathrm{~mol})(\mathbf{6 b})$ respectively.

The structure of these newly synthesized compounds of $\mathbf{7}(\mathbf{e}-\mathbf{h})$ were established by IR, ${ }^{1} \mathrm{H}-\mathrm{NMR},{ }^{13} \mathrm{C}-\mathrm{NMR}$, mass data and elemental analysis.

3-chloro-4-(1-((4-methylpiperazin-1-yl) methyl) - 1H - imidazol - 4 - yl) - 1 -phenylazetidin-2-one (7e) The product was synthesized according to general procedure $\mathbf{5 . 3}$ to afford the target compound as a white $0.48 \mathrm{~g}(68 \%)$ and $\mathrm{m} \mathrm{p} 142-144^{\circ} \mathrm{C}$.

IR (KBr 4000-400 cm-1): 3051 (stretching of Ar-H), 2940 and 2895 ( $\mathrm{CH}_{2}$ of aliphatic-CH), $1678(\mathrm{C}=\mathrm{O}$ of azetidinone), $1562(\mathrm{C}-\mathrm{N}), 1478$ 1360 (bending vibrations of imidazole ring), $1120(\mathrm{C}-\mathrm{O})$ and $725 \mathrm{~cm}^{-1}$ (C-Cl).

${ }^{1} \mathrm{H}-\mathrm{NMR}$ (400 MHz, DMSO-d $): \delta_{\mathrm{ppM}} 2.26\left(\mathrm{~s}, 3 \mathrm{H}, \mathrm{N}-\mathrm{CH}_{3}\right), 2.35$ ( $\mathrm{m}, 8 \mathrm{H}$ of methylpiperazin ring), $3.93(\mathrm{~m}, 1 \mathrm{H}, \mathrm{CH}$ of azetidine ring), $4.69(\mathrm{~d}, 1 \mathrm{H}, \mathrm{CH}$ of azetidine ring $\mathrm{J}=7.1 \mathrm{~Hz}), 4.80\left(\mathrm{~s}, 2 \mathrm{H}\right.$ of $\left.\mathrm{CH}_{2}\right), 5.39$ $(\mathrm{d}, 1 \mathrm{H}, \mathrm{CH}$ of azetidine ring $\mathrm{J}=7.1 \mathrm{~Hz}), 6.88(\mathrm{~s}, 1 \mathrm{H}, \mathrm{CH}$ of imidazole ring), 7.27-7.40 (m, $5 \mathrm{H}$ of phenyl ring) and $7.83(\mathrm{~s}, 1 \mathrm{H}$ of imidazole ring).

${ }^{13}$ C-NMR (75 MHz, DMSO-d $)_{6}: \delta_{\mathrm{PPM}} \cdot 137.2,118.8,137.8,40.9$, $68.5,199.4,54.3,139.2,128.1,128.8,126.0,128.8,128.1,75.8,52.6,57.3$, 
52.6, 57.3 and 46.6 corresponding to $\mathrm{C}_{1}$ to $\mathrm{C}_{19}$ respectively. MS 358.16 for $\mathrm{C}_{19} \mathrm{H}_{23} \mathrm{ClN}_{4} \mathrm{O}$. Anal. Found (Calcd) C, 63.59 (62.79); H, 6.46 (5.96); $\mathrm{N}, 15.61(15.01)$.

3-chloro-1-(4-chlorophenyl)-4-(1-((4-methylpiperazin-1-yl) methyl)-1H-imidazol-4-yl) azetidin-2-one (7f) The product was synthesized according to general procedure $\mathbf{5 . 3}$ to afford the target compound as a yellow solid with $0.51 \mathrm{~g}(66 \%)$ and $\mathrm{m} \mathrm{p} 147-149^{\circ} \mathrm{C}$.

IR (KBr 4000-400 cm-1): 3055 (stretching of Ar-H), 2940 and 2895 ( $\mathrm{CH}_{2}$ of aliphatic- $\left.\mathrm{CH}\right), 1690(\mathrm{C}=\mathrm{O}$ of azetidinone), $1558(\mathrm{C}-\mathrm{N}), 1475-$ 1366 (bending vibrations of imidazole ring), $1100(\mathrm{C}-\mathrm{O})$ and $728 \mathrm{~cm}^{-1}$ (C-Cl).

${ }^{1} \mathrm{H}-\mathrm{NMR}(400 \mathrm{MHz}$, DMSO-d $)$ ): $\delta_{\mathrm{PPM}} 2.26\left(\mathrm{~s}, 3 \mathrm{H}, \mathrm{N}-\mathrm{CH}_{3}\right), 2.35$ ( $\mathrm{m}, 8 \mathrm{H}$ of methylpiperazin ring), $3.93(\mathrm{~m}, 1 \mathrm{H}, \mathrm{CH}$ of azetidine ring), $4.69(\mathrm{~d}, 1 \mathrm{H}, \mathrm{CH}$ of azetidine ring $\mathrm{J}=7.1 \mathrm{~Hz}), 4.80\left(\mathrm{~s}, 2 \mathrm{H}\right.$ of $\left.\mathrm{CH}_{2}\right), 5.39$ $(\mathrm{d}, 1 \mathrm{H}, \mathrm{CH}$ of azetidine ring $\mathrm{J}=7.1 \mathrm{~Hz}), 6.88(\mathrm{~s}, 1 \mathrm{H}, \mathrm{CH}$ of imidazole ring), 7.42-7.45 (m, $4 \mathrm{H}$ of chloro phenyl ring) and 7.83 (s, $1 \mathrm{H}$ of imidazole ring).

${ }^{13}$ C-NMR (75 MHz, DMSO-d $): \delta_{\mathrm{PPM}} \cdot 137.2,118.8,137.8,40.9$, $68.5,199.4,54.3,137.3,129.5,128.9,131.6,128.9,129.5,75.8,52.6,57.3$, 52.6, 57.3 and 46.6 corresponding to $C_{1}$ to $C_{19}$ respectively. MS 392.12 for $\mathrm{C}_{19} \mathrm{H}_{22} \mathrm{Cl}_{2} \mathrm{~N}_{4} \mathrm{O}$. Anal. Found (Calcd) C, 58.02 (57.22); H, 5.64 (5.14); $\mathrm{N}, 14.24(13.64)$.

1-(4-bromophenyl)-3-chloro-4-(1-((4-methylpiperazin-1-yl) methyl)-1H-imidazol-4-yl) azetidin-2-one (7g) The product was synthesized according to general procedure $\mathbf{5 . 3}$ to afford the target compound as a yellow solid with $0.56 \mathrm{~g}(65 \%)$ and $\mathrm{m} \mathrm{p} 141-142^{\circ} \mathrm{C}$.

IR (KBr 4000-400 cm-1): 3050 (stretching of Ar-H), 2940 and 2895 $\left(\mathrm{CH}_{2}\right.$ of aliphatic- $\left.\mathrm{CH}\right), 1678$ ( $\mathrm{C}=\mathrm{O}$ of azetidinone), $1558(\mathrm{C}-\mathrm{N}), 1470$ 1360 (bending vibrations of imidazole ring), $1120(\mathrm{C}-\mathrm{O})$ and $714 \mathrm{~cm}$ ${ }^{1}(\mathrm{C}-\mathrm{Cl})$.

${ }^{1} \mathrm{H}-\mathrm{NMR}(400 \mathrm{MHz}$, DMSO-d $): \delta_{\mathrm{PPM}} 2.26\left(\mathrm{~s}, 3 \mathrm{H}, \mathrm{N}-\mathrm{CH}_{3}\right), 2.35$ (m, $8 \mathrm{H}$ of methylpiperazin ring), $3.93(\mathrm{~m}, 1 \mathrm{H}, \mathrm{CH}$ of azetidine ring), $4.69(\mathrm{~d}, 1 \mathrm{H}, \mathrm{CH}$ of azetidine ring $\mathrm{J}=7.1 \mathrm{~Hz}), 4.80\left(\mathrm{~s}, 2 \mathrm{H}\right.$ of $\left.\mathrm{CH}_{2}\right), 5.39$ $(\mathrm{d}, 1 \mathrm{H}, \mathrm{CH}$ of azetidine ring $\mathrm{J}=7.1 \mathrm{~Hz}), 6.88(\mathrm{~s}, 1 \mathrm{H}, \mathrm{CH}$ of imidazole ring), 7.18-7.82 ( $\mathrm{m}, 4 \mathrm{H}$ of bromo phenyl ring) and $7.83(\mathrm{~s}, 1 \mathrm{H}$ of imidazole ring).

${ }^{13}$ C-NMR (75 MHz, DMSO-d $): \delta_{\mathrm{PPM} \cdot} \cdot 137.2,118.8,137.8,40.9$, $68.5,199.4,54.3,138.2,130.3,131.7,120.4,131.7,130.3,75.8,52.6$, $57.3,52.6,57.3$ and 46.6 corresponding to $\mathrm{C}_{1}$ to $\mathrm{C}_{19}$ respectively. MS 436.07 for $\mathrm{C}_{19} \mathrm{H}_{22} \mathrm{BrClN}_{4} \mathrm{O}$. Anal. Found (Calcd) C, 52.13(51.33); H, 5.07 (5.57); N, 12.80 (12.00).

3 - chloro - 4-(1-((4-methylpiperazin-1-yl) methyl) -1Himidazol-4-yl) - 1 - (4-nitrophenyl) azetidin-2-one (7h) The product was synthesized according to general procedure 5.3 to afford the target compound as a yellow solid with $0.54 \mathrm{~g}(68 \%)$ and $\mathrm{m} \mathrm{p} 155-157^{\circ} \mathrm{C}$.

IR (KBr 4000-400 cm-1): 3068 (stretching of Ar-H), 2940 and 2895 ( $\mathrm{CH}_{2}$ of aliphatic- $\left.\mathrm{CH}\right), 1692(\mathrm{C}=\mathrm{O}$ of azetidinone), $1558(\mathrm{C}-\mathrm{N}), 1550$ $1330\left(\mathrm{C}-\mathrm{NO}_{2}\right), 1480-1369$ (bending vibrations of imidazole ring), 1116 (C-O) and $726 \mathrm{~cm}^{-1}(\mathrm{C}-\mathrm{Cl})$.

${ }^{1} \mathrm{H}-\mathrm{NMR}(400 \mathrm{MHz}$, DMSO-d $): \delta_{\mathrm{PPM}} 2.26\left(\mathrm{~s}, 3 \mathrm{H}, \mathrm{N}-\mathrm{CH}_{3}\right), 2.35$ ( $\mathrm{m}, 8 \mathrm{H}$ of methylpiperazin ring), $3.93(\mathrm{~m}, 1 \mathrm{H}, \mathrm{CH}$ of azetidine ring), $4.69(\mathrm{~d}, 1 \mathrm{H}, \mathrm{CH}$ of azetidine ring $\mathrm{J}=7.1 \mathrm{~Hz}), 4.80\left(\mathrm{~s}, 2 \mathrm{H}\right.$ of $\left.\mathrm{CH}_{2}\right), 5.39$ $(\mathrm{d}, 1 \mathrm{H}, \mathrm{CH}$ of azetidine ring $\mathrm{J}=7.1 \mathrm{~Hz}), 6.88(\mathrm{~s}, 1 \mathrm{H}, \mathrm{CH}$ of imidazole ring), $7.83(\mathrm{~s}, 1 \mathrm{H}$ of imidazole ring) and $7.55-8.21(\mathrm{~m}, 4 \mathrm{H}$ of chloro phenyl ring).

${ }^{13}$ C-NMR (75 MHz, DMSO-d $): \delta_{\mathrm{PPM}} \cdot 137.2,118.8,137.8,40.9$,
$68.5,199.4,54.3,145.3,129.0,124.0,145.2,124.0,129.0,75.8,52.6$ $57.3,52.6,57.3$ and 46.6 corresponding to $C_{1}$ to $C_{19}$ respectively. MS 403.14 for $\mathrm{C}_{19} \mathrm{H}_{22} \mathrm{ClN}_{5} \mathrm{O}_{3}$. Anal. Found (Calcd) C, 56.51 (55.71); H, 5.49 (4.99); N, 17.34 (16.74).

\section{Result and Discussion}

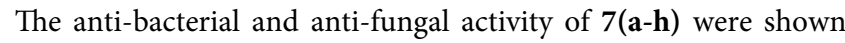
in the Table 1 . The compounds $7(\mathrm{a}-\mathrm{h})$ were tested for antimicrobial activity. Amongst all the tested compounds, $7 \mathrm{~b}-\mathrm{d}$ and $7 \mathrm{f}-\mathrm{h}$ exhibited higher activity than other which may be due to the presence of electron withdrawing substituents increases the activity when compared with electron donating substituents.

\section{Conclusion}

In conclusion, we have demonstrated the synthesis of a series of novel N-Mannich Bases of Imidazole phenylazetidin-2-ones derivatives with different substituents. Some of the compounds were found to have good antimicrobial activity.

\section{Acknowledgement}

The author V. Esther Rani thanks to U G C - S A P and U G C - B S R, New Delhi for financial assistance. They are also thankful to IICT Hyderabad and CDRI Lucknow for spectral and analytical data.

\section{References}

1. Wallace OB, Lauwers KS, Jones SA, Dodge JA (2003) Tetrahydroquinolinebased selective estrogen receptor modulators (SERMs). Bioorg Med Chem Lett 13: 1907-1910.

2. Benito S, Pedro A (2004) $\beta$-Lactams as Versatile Synthetic Intermediates for the Preparation of Heterocycles of Biological Interest. Current medicinal Chemistry 1: 1921-1949.

3. Georg GI (1993) The Organic Chemistry of ß-lactams, VCH: New York.

4. Knowles JR (1985) Penicillin resistance: the chemistry of .beta.-lactamase inhibition. Acc Chem Res 18: 97-104.

5. Buttero PD, Molteni G, Pilati T (2003) Nitrilimine cycloaddition to 4-(pyrazol5-yl)carbonyl-2-azetidinone and 4-(pyrazol-4-yl)carbonyl-2-azetidinone. Tetrahedron Letter 44: 1425-1427.

6. Guner V, Yildirir S, Ozcelik B, Abbasoglu U (2000) Synthesis and antimicrobia activity of ,4-diaryl-2-azetidinones. Farmaco 55: 147-150.

7. Singh VP, Saxsena KK, Bhati SK, Kumar AJ (2010) Global PharmaTech 2: 42

8. Veinberg G, Shestakoval I, Voron M, Kanepe I, Lukevics E (2004) Synthesis of antitumor 6-alkylidenepenicillanate sulfones and related 3-alkylidene-2azetidinones. Bioorg Med Chem Letts 14: 147

9. Naute AS, Khedekar PB, Bhusari KP (2008) QSAR studies on 4-thiazolidinones and 2-azetidinones bearing benzothiophene nucleus as potential anti-tubercular agents. Ind J Chem 47B: 586-591.

10. Banik BK, Becker FF, Banik I (2004) Synthesis of anticancer beta-lactams: mechanism of action. Bioorg Med Chem 12: 2523-2528.

11. Veinberg G, Bokaldere R, Dikoskaya K, Vorona M, Kanepe I, et al. (2003) Synthesis of Cytotoxic 1,3,4-trisubstituted 2-azetidinones. Chem Het Comp 39: 587-593.

12. Veinberg G, Bokaldere R, Dikoskaya K, Vorona M, Turovski, Kanepe. I, et al. (2005) Synthesis of cytotoxic derivatives of 2-oxo-1-azetidinylacetamide. Chem Het Comp 41: 93-97.

13. Gerard S, Dive G, Clamot B, Touillaux R, Marchand B (2002) Synthesis hydrolysis, biochemical and theoretical evaluation of 1,4-bis(alkoxycarbonyl) azetidin-2-ones as potential elastase inhibitors. J Tetrahedron 58: 2423-2433.

14. Wang Y, Zhang H, Huang W, Kong J, Zhou J, et al. (2009) 2-Azetidinone derivatives: design, synthesis and evaluation of cholesterol absorption inhibitors. Eur J Med Chem 44: 1638-1643.

15. Parekh J, Inamdhar P, Nair R, Baluja S, Chanda S (2005) Synthesis and antibacterial activity of some Schiff bases derived from 4-aminobenzoic acid Journal of the Serbian Chemical Society 70: 1155-1158. 
Citation: Rani VE, Kumar KD (2015) Synthesis and Antimicrobial Activity of Some Novel N-Mannich Bases of Imidazole Phenylazetidin-2-one. Med chem 5: 154-159. doi:10.4172/2161-0444.1000258

16. Deepak Wadhwa, Varun Arora, Khalid Hussain, Pragi Arora (2014) a-Tosyloxyacetophenones: As a precursor in ultrasonic assisted multicomponent, diastereoselective synthesis of trans-2,3-dihydrofuro[3,2-c] coumarins using $[\mathrm{BMIm}] \mathrm{OH}$ and their antimicrobial evaluation. Journal of Chemical and Pharmaceutical Research 6: 655-661.
17. Magaldi S, Mata-Essayag S, Hartung de Capriles C, Perez C, Colella MT, et al. (2004) Well diffusion for antifungal susceptibility testing. Int J Infect Dis 8: $39-45$. 